\title{
Physical and chemical attributes of a soil cultivated with rubber tree under three management strategies
}

\section{Atributos físicos e químicos de um solo cultivado com seringueira sob três sistemas de manejo}

\author{
Yuri Luiz Augusto dos Santos ${ }^{1 *}$; Adriana Aparecida Ribon²; Luis Filipe Caixeta \\ Bitencourt $^{3}$; Leonardo Rodrigues Barros ${ }^{4}$; Kathleen Fernandes ${ }^{5}$; Vladia Correchel ${ }^{6}$; \\ Wilson Mozena Leandro ${ }^{6}$; Clarice Backes ${ }^{7}$; Alessandro José Marques Santos ${ }^{7}$; \\ Pedro Rogério Giongo ${ }^{8}$
}

\section{Highlights:}

São escassos os estudos apontando o assunto.

O experimento fornece informações que auxiliam na escolha de manejo mais adequado.

Os benefícios socioambientais da haveicultura.

Utilização de dejetos de aves, até então descartados, na produção do organomineral.

\begin{abstract}
Rubber tree (Hevea brasiliensis) is a native species of the Amazon biome. This species had great economic importance due to the production of latex, used to obtain natural rubber. Seeking growth in productivity with adequate management is necessary to optimize production and increase areas with rubber trees. This study aimed to verify the physical and chemical attributes of soil under three different managements and two rubber tree clones, searching for the best alternative for the general edaphoclimatic conditions of the Cerrado biome. The experiment was installed in Palmeiras of Goiás, $\mathrm{GO}$, Brazil, in a randomized block design in a $2 \times 3$ factorial arrangement, consisting of two rubber tree clones (PB 312 and RRIM 600) and three management strategies (organomineral fertilizer with poultry litter, pigeon pea as green manure, and mechanical mowing-brushcutter). Physical attributes such as soil density, soil penetration resistance, soil moisture and aggregation, soil fertility, and tree development were analyzed. Statistical analyses of variance and Tukey test were carried out in order to compare the dendrometric data and physical and chemical attributes of the soil under the different treatments applied in the inter-row of rubber trees. No significant statistical differences were found among treatments and between clones in relation to soil physical attributes. However, the soil $\mathrm{pH}$ reduced the use of organomineral fertilizer and the clone RRIM 600 had the highest heights.
\end{abstract}

Key words: Hevea brasiliensis. Fertility. Rubber cultivation. Red Latosol. Organomineral fertilizer.

${ }^{1}$ Eng $^{\circ}$ Florestal, Mestre em Desenvolvimento Rural Sustentável, Universidade Estadual de Goiás, UEG, São Luis de Montes Belos, GO, Brasil. E-mail: ylas89@gmail.com

2 Prof., Dr., UEG, Palmeiras de Goiás, GO, Brasil. E-mail: adriana.ribon@ueg.br

3 Eng ${ }^{\circ}$ Ag $^{\text {o }}$ UEG, Palmeiras de Goiás, GO, Brasil. E-mail: lfagro14@gmail.com

4 Prof. Dr., Departamento de Agronomia, Universidade do Estado de Mato Grosso, UNEMAT, Cáceres, MT, Brasil. E-mail: barros.solos@gmail.com

5 Discente do Curso de Doutorado, Programa de Pós-Graduação em Agronomia, Departamento de Solos, Faculdade de Ciências Agrárias e Veterinária, Universidade Estadual Paulista, UNESP, Jaboticabal, SP, Brasil. E-mail: klfagronomia@gmail.com

6 Profs. Drs., Departamento de Solos, UFG, Campus Samambaia, GO, Brasil. E-mail: vladiacorrechel@hotmail.com; wilsonufg@ gmail.com

7 Profs. Drs., UEG, São Luis de Montes Belos, GO, Brasil. E-mail: clarice.backes@ueg.br; alessandro.santos@ueg.br

8 Prof. Dr., UEG, Santa Helena de Goiás, GO, Brasil. E-mail: pedro.giongo@ueg.br

* Autho for correspondence 


\title{
Resumo
}

\begin{abstract}
A seringueira (Hevea brasiliensis) é uma espécie nativa do bioma Amazônia. Esta espécie teve grande importância econômica devido à produção de látex usada para obter borracha natural. Para otimizar a produção e aumentar as áreas com seringueiras, é necessário buscar um crescimento da produtividade com manejo adequado. O objetivo deste trabalho foi verificar os atributos físicos e químicos do solo com três diferentes manejos e dois clones de seringueira, buscando a melhor alternativa para as condições edafoclimáticas gerais do bioma Cerrado. O experimento foi instalado em Palmeiras de Goiás - GO, Brasil, e com um bloco randomizado, em esquema fatorial (2x3), considerando os dois clones (PB $312 \mathrm{e}$ RRIM 600) como três manejos (fertilizante organomineral) com cama de aves de capoeira; adubo verde - ervilha de pombo e roçadeira mecânica). Foram analisados atributos físicos como densidade do solo, resistência do solo à penetração, umidade e agregação, bem como fertilidade do solo e desenvolvimento das árvores. Análises estatísticas de variância e teste de Tukey foram realizadas para comparar dados dendrométricos e atributos físicos e químicos do solo nos diferentes tratamentos aplicados na entrelinha do cultivo da seringueira. Não foram encontradas diferenças estatísticas significativas entre os tratamentos e entre os clones em relação aos atributos físicos do solo. No entanto, o pH do solo reduziu com o uso de organomineral e o clone RRIM 600 apresentou os maiores resultados de altura.
\end{abstract}

Palavras-chave: Hevea brasiliensis. Fertilidade. Haveicultura. Latossolo. Organomineral.

\section{Introduction}

The intensive soil use pooled with the reduction of natural vegetation cover can be supply to the degradation of natural resources and, mainly, the decreasing of soil fertility. Briefly, these degradation processes can occur through inadequate management methods that favor erosion and soil organic matter loss (Santos \& Salcedo, 2010). The demand for woody crops that relieve the consequences of soil degradation has been increasing, aiming to mitigate the negative impact of improper management. One representative of these crops is the rubber tree, which is a forest species of importance for sustainable economic development due to latex production and carbon storage capacity (Maggiotto et al., 2014; Galvão et al., 2016).

The study of edaphic attributes allows the quantification, magnitude, and duration of changes caused by different management practices that lead to alterations in soil attributes, indicating loss of quality and affecting the environmental and economic sustainability of crops (Niero, Falci, Marques, \& Clerici, 2010; Silveira, Melo, Sacramento, \& Silveira, 2010). Soil physical properties are widely studied, as they influence crop productivity and sustainability because of the type of management it undergoes, detecting changes in quality (Carneiro, Souza, Reis, Pereira, \& Azevedo, 2009; E. Q. Cunha, Stone, Ferreira, Didonet, \& Moreira, 2012; Vasconcelos, Souza, Cantalice, \& Silva, 2014). According to Pott, Zerbielli, Martins, Gardin, \& Garcia (2017), the soil physical quality can also be noteworthy, as it influences chemical and biological qualities.

According to Torres, Jacovine, Brianezi and Alves (2014), the number of studies on soil conservation and management has been increasing due to the concern with the decoupling between sustainable development and economic growth. The increasing fertilizer use is a major concern, as the excess of nutrients in the soil can decrease its fertility, affecting plant growth and increasing the risk of contamination by leaching (Good \& Beatty, 2009; Albornoz, 2016; Trabaquini, Galvão, Formaggio, \& Aragão, 2017).

The use of management strategies with green manure and organomineral fertilizer (organic fertilizers enriched with mineral nutrients) is an alternative to maintain sustainability in cropping systems under highly weathered soils and climate 
with a predominance of long periods of drought, as observed in the Cerrado biome. These practices are economically and environmentally important, reducing costs with synthetic fertilizers, improving soil properties, and contributing to maintaining an adequate soil fertility together with the reduction of impacts on natural resources (Cardoso, Silva, Moreira, \& Curi, 2009; Ferreira, Souza, \& Chaves, 2012).

Studies related to rubber tree fertilization have emphasized the macronutrients for the application of fertilizers based on $\mathrm{N}$ (nitrogen), $\mathrm{P}$ (phosphorus), $\mathrm{K}$ (potassium), and $\mathrm{Mg}$ (magnesium) to obtain optimal latex yields (Oku, Iwara, \& Ekukinam, 2012). In addition, Verheye (2010) suggested that fertilizer application should take priority during the stage of vegetative development, that is, the first six years, as fertilization with NPK contributes to its rapid growth at this stage.

Besides the correct management, another factor that influences rubber tree productivity is genetic material. The relationship between soil type and genetic material is important for productivity, as clones reach their potential under favorable edaphoclimatic conditions. The clone RRIM 600 is commonly cultivated in Brazil due to its vigor and productivity, presenting tall trees, vertical stem, and fast growth (when young). The clone PB 312, belonging to the PB 300 series, is little indicated because it is still experimental but has increased its production over the years (Instituto Agronômico de Campinas [IAC], 2018).

However, few studies have investigated the environmental and ecological effects of rubber tree production. The relationship between intensive crop cultivation and soil physical and chemical properties remains largely unknown (Zhang et al., 2017). In this context, this study aimed to evaluate the soil physical and chemical attributes and the development of two rubber tree clones under three management strategies.

\section{Methodology}

\section{Experimental area}

This study was developed in a medium-textured soil classified by EMBRAPA(Empresa Brasileira de Pesquisa e Agropecuária [EMBRAPA], 2013) as a Red Latosol (Oxisol, USDA soil taxonomy), located in Palmeiras de Goiás, GO, Brazil (16²5'28.3" S $50^{\circ} 04^{\prime} 55.6^{\prime \prime} \mathrm{W}$ ), on the Baru Farm. The Cerrado sensu stricto (Brazilian savannah) was predominant in the original vegetation, which was suppressed in 1970 for the establishment of Brachiaria sp. Soil management for rubber tree planting started in 2013 when the area had an intense process of degradation.

The Köppen climate classification for the region is Aw, that is, a tropical climate with a dry winter season, presenting two defined seasons, annual rainfall of approximately $1751 \mathrm{~mm}$ and an average temperature of $22.9{ }^{\circ} \mathrm{C}$ (Alvares, Stape, Sentelhas, Gonçalves, \& Sparpvek, 2013). Precipitation reached only $0.02 \mathrm{~mm}$ in August when the data were collected in the experimental area.

The soil had the following chemical properties at a depth of $0-20 \mathrm{~cm}$ at the beginning of the experiment (2013): $\mathrm{pH}\left(\mathrm{CaCl}_{2}\right)$ of 5.6, $\mathrm{P}$ of $9 \mathrm{mg}$ $\mathrm{dm}^{-3}, \mathrm{Mg}$ of $0.8 \mathrm{cmol}_{\mathrm{c}} \mathrm{dm}^{-3}, \mathrm{Ca}$ of $3.3 \mathrm{cmol}_{\mathrm{c}} \mathrm{dm}^{-3}$, $\mathrm{K}$ of $105 \mathrm{mg} \mathrm{dm}^{-3}$, and sand, silt, and clay of 48, 13, and $39 \%$, respectively.

Dolomitic limestone (79\% RNV and 92\% NV) was applied in the area in October 2013 without incorporation at the dose of $3 \mathrm{t} \mathrm{ha}^{-1}$. Planting fertilization was carried out in the pits with $250 \mathrm{~g}$ NPK (11-44-00) + 10\% FTE BR-12 per seedling. Topdressing fertilization was performed after one year with 60 g NPK (20-00-20) per plant. No soil tillage with machinery was carried out, but local tillage was conducted to open pits. Planting was carried out in February 2014, with a spacing of $6 \times$ 3.3 m with clones RRIM 600 and PB-312. 


\section{Experimental design and treatments}

This study was set up in a randomized block design with two rubber tree clones (RRIM 600 and PB-312) and three management strategies (organomineral fertilizer with poultry litter, mowing followed by mineral fertilizer application, and green manure with pigeon pea (Cajanus cajan (L.) Hunth) as a cover crop), with five replications. The useful plot was the ten central trees (Figure 1).
PB 312

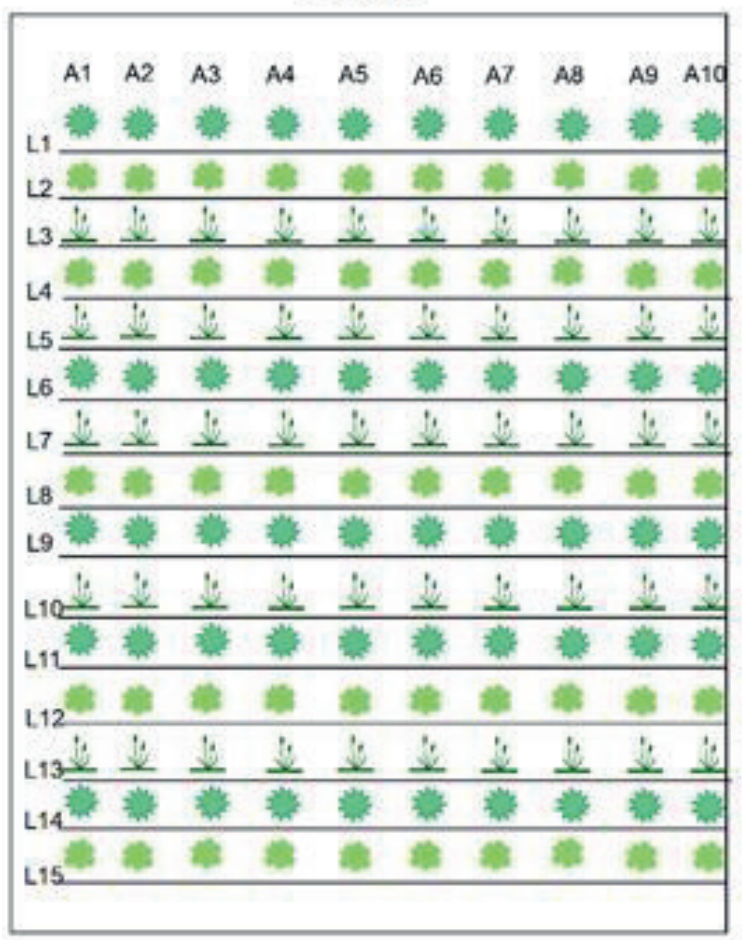

RRIM 600

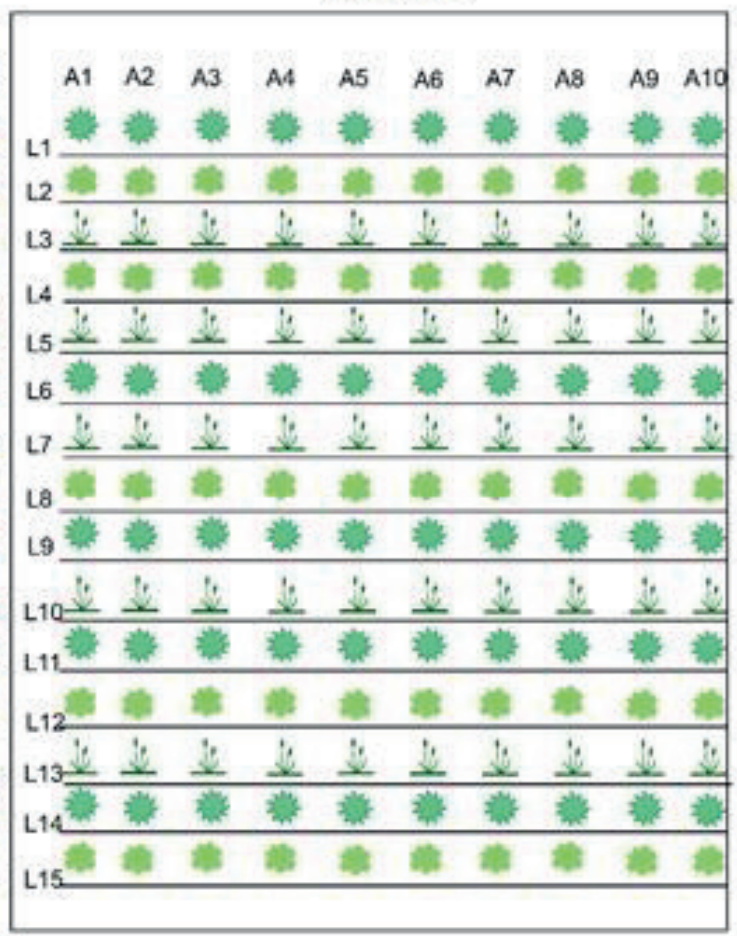

Pigeon pea (Cajanus cajan)

Figure 1. Layout of the experimental area.

Management practices were performed before the experiment set up on the rubber tree inter-row spacing and consisted of manual weeding in the planted region, application of herbicide Goal ${ }^{\circledR}$, desiccation with glyphosate, and mechanical mowing using a brush-cutter. Mechanical mowing was carried out three times a year during the rainy season, with the plant material ground and applied in the inter-row spacing. The Legume (pigeon pea) was sown at the density of $297 \mathrm{~g}$ of seeds per row, with one mowing per year. The organomineral fertilizer (poultry litter) was broadcast applied once a year in the inter-row spacing at the dose of 20 $\mathrm{kg}$ per row, without incorporation. It was enriched with phosphate rock and potassium chloride and had the following composition: $5.05 \mathrm{~g} \mathrm{~kg}^{-1}$ of potassium $\left(\mathrm{K}_{2} \mathrm{O}\right), 3.80 \mathrm{~g} \mathrm{~kg}^{-1}$ of calcium, $1 \mathrm{~g} \mathrm{~kg}^{-1}$ of magnesium, $2.05 \mathrm{~g} \mathrm{~kg}^{-1}$ of sulfur, $0.90 \mathrm{~g} \mathrm{~kg}^{-1}$ of iron, $710 \mathrm{mg} \mathrm{dm}^{-3}$ of manganese, $140 \mathrm{mg} \mathrm{dm}^{-3}$ of copper, $730 \mathrm{mg} \mathrm{dm}^{-3}$ of zinc, $240 \mathrm{mg} \mathrm{dm}^{-3}$ of boron, and $0.57 \mathrm{~g} \mathrm{~kg}^{-1}$ of sodium, with $\mathrm{pH}$ of 8.9 .

\section{Analysis of soil physical attributes}

Soil aggregate stability was analyzed using undisturbed samples collected at a depth of 0-0.20 
m in August 2018 within the rubber tree crown projection of all plots. In the first step, these samples were sieved through 8 and $4 \mathrm{~mm}$ mesh sieves, being then wet sieved using $2,1,0.50,0.25$, and 0.105 $\mathrm{mm}$ mesh sieves, following the method proposed by Yoder (1936). The mean weight diameter of waterstable aggregates was calculated by the method described by Kemper and Chepil (1965).

The soil penetration resistance (PR) data were collected in August 2018 using an IAA/Planalsucar/ Stolf impact penetrometer, in which the number of impacts $\left(\mathrm{dm}^{-1}\right)$ was transformed into dynamic resistance $(\mathrm{MPa})$ using the equation proposed by Stolf (1991), and the obtained result was multiplied by the constant 0.098 .

Soil density (volumetric ring method) was determined using soil samples collected in three points at each row, and the total porosity was obtained through the saturation volume of the sample, both according to the method described by EMBRAPA (Empresa Brasileira de Pesquisa e Agropecuária [EMBRAPA], 2017). The soil organic carbon stratification rate was calculated by the quotient of soil organic carbon contents at the same depths of the samples for the aggregate analysis (Franzluebbers, 2002).

Soil texture analysis was determined on disturbed samples using $\mathrm{NaOH}$ dispersion $(0.1 \mathrm{~mol}$ $\mathrm{L}^{-1}$ ) and slow stirring for 16 hours. Clay content was obtained by the pipette method, while clay dispersed in water was obtained by EMBRAPA (2017).

\section{Analysis of soil chemical attributes}

Soil chemical analysis was carried out using two simple soil samples collected at a depth of 0-0.20 $\mathrm{m}$ in all replications of treatments using a Dutch auger, giving rise to a composite sample for each row in the rubber tree clones. These samples were analyzed at the Laboratory of Soil Fertility of the Federal University of Goiás (UFG) to determine the $\mathrm{pH}$ in water and $\mathrm{CaCl}_{2}$ solution, available $\mathrm{K}$ and $\mathrm{P}$ contents by the Mehlich I extractor, the exchangeable $\mathrm{Ca}, \mathrm{Mg}, \mathrm{Al}$, and $\mathrm{H}+\mathrm{Al}$ contents, base saturation (V), aluminum saturation (m), and cation exchange capacity (CEC), following methodologies by EMBRAPA (2017).

\section{Analysis of the development of rubber trees}

The development of rubber tree clones was evaluated by dendrometric characteristics, height, and perimeter (sampled at chest height, i.e., $1.30 \mathrm{~m}$ ) in August 2018. Ten individuals were measured in each of the five replications of the three management strategies.

\section{Statistical analysis}

The data of soil chemical and physical attributes were submitted to analysis of variance (ANOVA), considering a completely randomized model with five replications to evaluate the effect on rubber clones and management strategies. The t-test at 5\% was used for the comparison of means.

\section{Results and Discussion}

\section{Soil physical attributes}

The results showed no significant differences between the means of soil aggregates retained on the sieves, as well as between treatments and between clones for soil organic matter (Table 1 and Figure 2 ). These results differ from those find by Souza, Silva, Oliveira, Barbosa and Silva (2018), who found high soil aggregate stability in a Ultisol in the organomineral fertilization of areas with coffee after one year of implementation. 


\section{Table 1}

Means of aggregates retained in 2, 1, 0.5, 0.25, and $0.105 \mathrm{~mm}$ sieves from a Red Latosol at a depth of 0-0.20 $\mathrm{m}$ cultivated with the rubber tree clones PB 312 (C1) and RRIM 600 (C2). Treatments (Treat) are O- organomineral, BRU - brushcutter, and PG - pigeon pea. Mean weight diameter (MWD). Means followed by the same letter do not differ from each other by the Tukey test $(\mathbf{p}<\mathbf{0 . 0 5})$. Lowercase letters compare management strategies, and uppercase letters compare clones

\begin{tabular}{|c|c|c|c|c|c|c|c|}
\hline \multirow[b]{2}{*}{ Clone } & \multicolumn{6}{|c|}{ Sieve } & \multirow[b]{2}{*}{ MWD } \\
\hline & Treat & 2 & 1 & 0.5 & 0.25 & 0.105 & \\
\hline & & & & $\%$ & & & $(\mathrm{~mm})$ \\
\hline PB 312 & $\mathrm{O}$ & $81.18 \mathrm{Aa}$ & $1.94 \mathrm{Aa}$ & $2.25 \mathrm{Aa}$ & $2.03 \mathrm{Aa}$ & $1.49 \mathrm{Aa}$ & $2.53 \mathrm{Aa}$ \\
\hline PB 312 & BRU & $82.13 \mathrm{Aa}$ & $1.97 \mathrm{Aa}$ & $1.84 \mathrm{Aa}$ & $1.53 \mathrm{Aa}$ & $0.94 \mathrm{Aa}$ & $2.56 \mathrm{Aa}$ \\
\hline PB 312 & PG & $85.59 \mathrm{Aa}$ & $1.48 \mathrm{Aa}$ & $1.54 \mathrm{Aa}$ & $1.15 \mathrm{Aa}$ & $0.87 \mathrm{Aa}$ & $2.53 \mathrm{Aa}$ \\
\hline RRIM 600 & $\mathrm{O}$ & $81.54 \mathrm{Aa}$ & $2.07 \mathrm{Aa}$ & $2.50 \mathrm{Aa}$ & $1.81 \mathrm{Aa}$ & $0.95 \mathrm{Aa}$ & $2.50 \mathrm{Aa}$ \\
\hline RRIM 600 & BRU & $85.13 \mathrm{Aa}$ & $1.56 \mathrm{Aa}$ & $1.73 \mathrm{Aa}$ & $1.81 \mathrm{Aa}$ & $1.06 \mathrm{Aa}$ & $2.61 \mathrm{Aa}$ \\
\hline RRIM 600 & PG & $85.68 \mathrm{Aa}$ & $1.60 \mathrm{Aa}$ & $1.64 \mathrm{Aa}$ & $1.11 \mathrm{Aa}$ & $0.65 \mathrm{Aa}$ & $2.61 \mathrm{Aa}$ \\
\hline
\end{tabular}

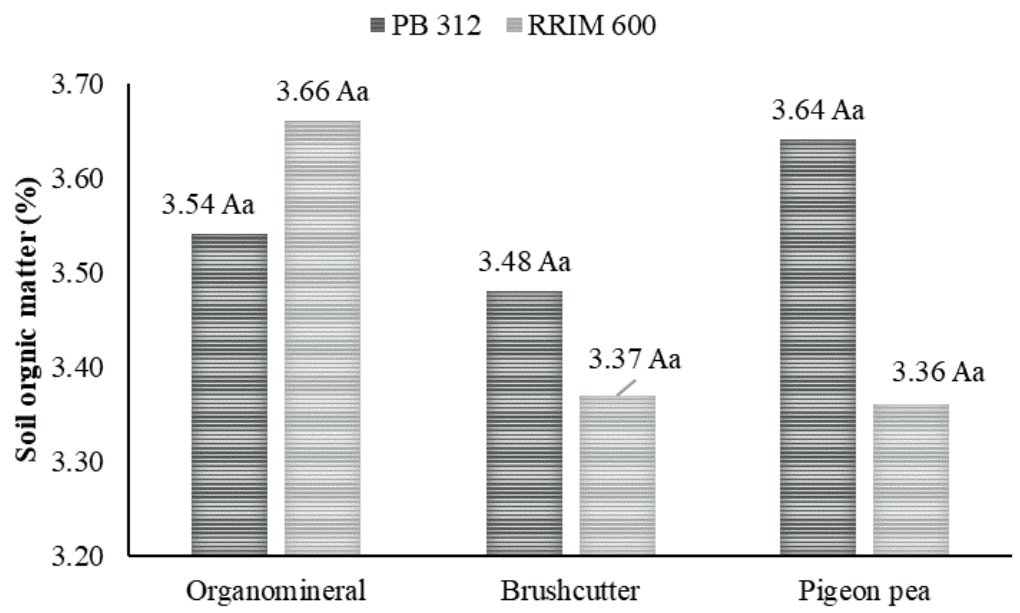

Figure 2. Levels of soil organic matter in the three management systems for clones PB312 and RRIM600. Means followed by the same letter do not differ from each other by the Tukey test $(p<0.05)$. Uppercase letters compare management strategies within the same clone, while lowercase letters compare clones within the same management.

Soil aggregate stability is related to the quantification of soil organic matter and depends on several factors, such as soil use and management, texture, mineralogy, and amount and type of soil organic matter (Almeida et al., 2014). In this study, rubber trees are still young, with no latex production, and the low leaf senescence is not able to produce high amounts of organic matter due to litter production. Nanzer et al. (2019) conducted a study with total organic carbon stock and particle size fractionation of organic matter in soil use systems in the Cerrado and found that rubber trees at 30 years of age could aggregate high benefits to the soil through organic matter addition in the medium and long term.

A high proportion of aggregates retained on the $2 \mathrm{~mm}$ sieve was found for all treatments at a depth of 0-0.2 m. No significant difference was observed between treatments and between clones for all sieves. 
The aggregate stability index showed that the mean weight diameter (MWD) showed no significant differences between treatments at the analyzed depth. The MWD values are similar to those found by A. F. Portugal, Juncksh, Schaefer and Neves (2010) in a dystrophic Red-Yellow Argisol cultivated with rubber trees, with values of $2.31 \mathrm{~mm}$ at a depth of $0-10 \mathrm{~cm}$ and $2.17 \mathrm{~mm}$ at a depth of $10-20 \mathrm{~cm}$. However, the MWD values found in this study are lower than the values observed by Valani, Oliosi, Gontijo and Partelli (2016) in a monoculture of rubber tree in the State of Espírito Santo, with values of $4.44 \mathrm{~mm}$ at a depth of $0-10 \mathrm{~cm}$ and 4.39 $\mathrm{mm}$ at a depth of 10-20 cm. Aggregates with high MWD values do no mean an adequate pore size distribution, interfering with structural quality
(Bertol, Alburquerque, Leite, Amaral, \& Zoldan, 2004).

The management with mechanical mowing showed a statistically significant difference between the means of total soil porosity of clones. The total soil porosity with the clone RRIM 600 showed the highest value (Figure 3). No statistical differences were observed between the remaining treatments. Soil porosity is an important measure of soil quality, as it is related to the soil water infiltration rate (F. V. Cunha, Pereira, Leles, \& Abel, 2018). Zaninetti, Moreira and Moraes (2016) found a high percentage of total soil porosity (58.4\%) in a six-year-old rubber tree field under a dystrophic Yellow Latosol at a depth of $0.10 \mathrm{~m}$.

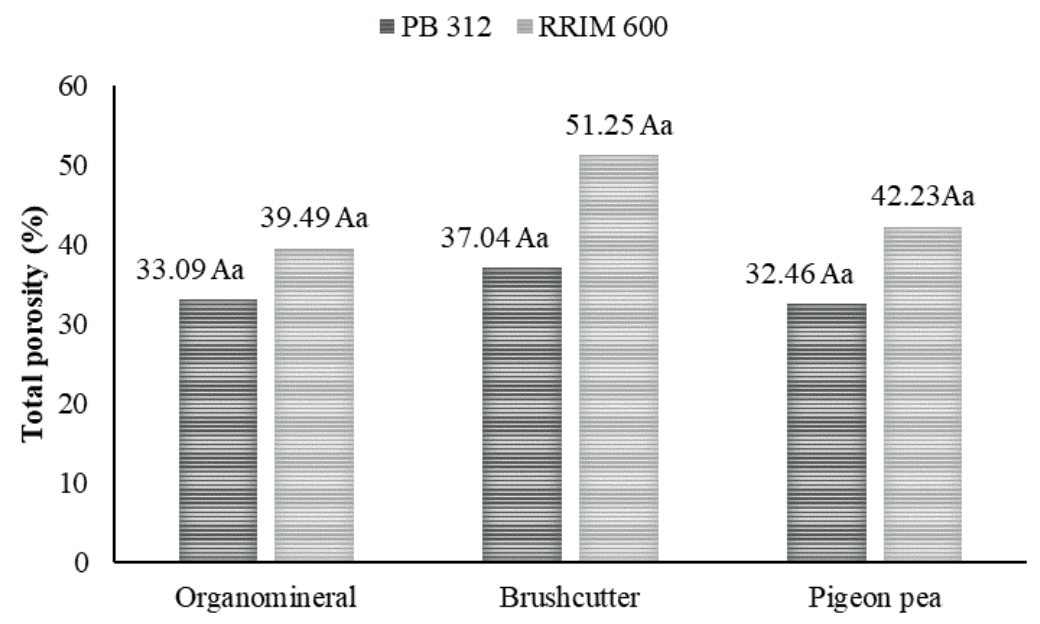

Figure 3. Mean total porosity $\left(\mathrm{dm}^{3} \mathrm{dm}^{-3}\right)$ of a Red Latosol obtained after different fertilization management strategies in a rubber tree field. Means followed by the same letter do not differ from each other by Tukey's test $(\mathrm{p}<0.05)$. Uppercase letters compare management strategies within the same clone, while lowercase letters compare clones within the same management.

Little information can be found in the literature on the limits of total porosity that impairs the root development of rubber trees. However, the value of $0.5 \mathrm{dm}^{3} \mathrm{dm}^{-3}$ has been accepted as ideal for performing soil functions.
Ribeiro et al. (2016) observed that the increased amount of organic fertilizer (organomineral) composed of turkey litter provided a reduction in soil density and high total pore volume in the State of Goiás, with a recommended application of 10.4 $\mathrm{mg} \mathrm{ha}^{-1}$ of turkey litter. 
Treatment application did not significantly affect $(\mathrm{p}>0.05)$ soil density $\left(\mathrm{S}_{\mathrm{d}}\right)$ (Figure 4$)$. Clone RRIM 600 under mechanical mowing is in accordance with the maximum value proposed by Reichert, Reinert and Braida (2003), who observed an efficient root system development under $\mathrm{S}_{\mathrm{d}}$ between 1.3 and $1.4 \mathrm{~g}$ $\mathrm{cm}^{-3}$ for clayey soils. The values found in this study for the analyzed soil layer $(0-0.20 \mathrm{~m})$ are higher than the critical value.

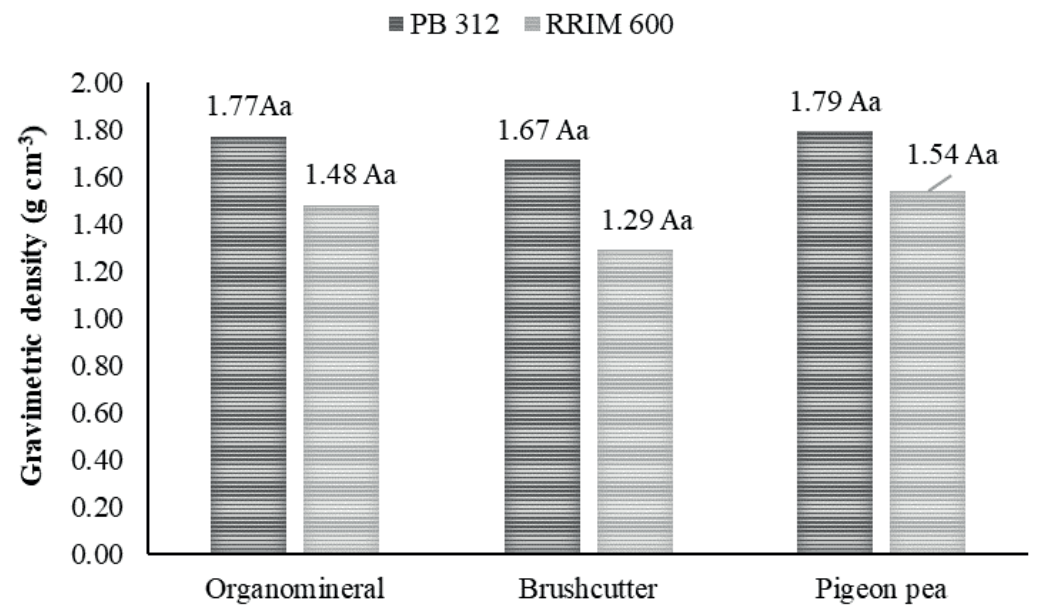

Figure 4. Gravimetric density $\left(\mathrm{g} \mathrm{cm}^{-3}\right)$ of a Red Latosol obtained after different fertilization management strategies in a rubber tree field. Means followed by the same letter do not differ from each other by Tukey's test $(\mathrm{p}<0.05)$. Uppercase letters compare management strategies within the same clone, while lowercase letters compare clones within the same management.

Rosa, Alves, Souza, Bonini and Videira (2017) observed that the addition of organic matter to the soil using green manure provided benefits on the quality of soil physical attributes, total porosity, and soil density, recovering soil structure over the years. However, long-term studies are needed to verify the efficiency of the management with pigeon pea.
No significant difference was observed between treatments and clones (Figure 5). This result differs from the results obtained by Alvarenga (1993), who conducted an experiment comparing different green manures and observed a high potential for root penetration in the soil cultivated with pigeon pea. 


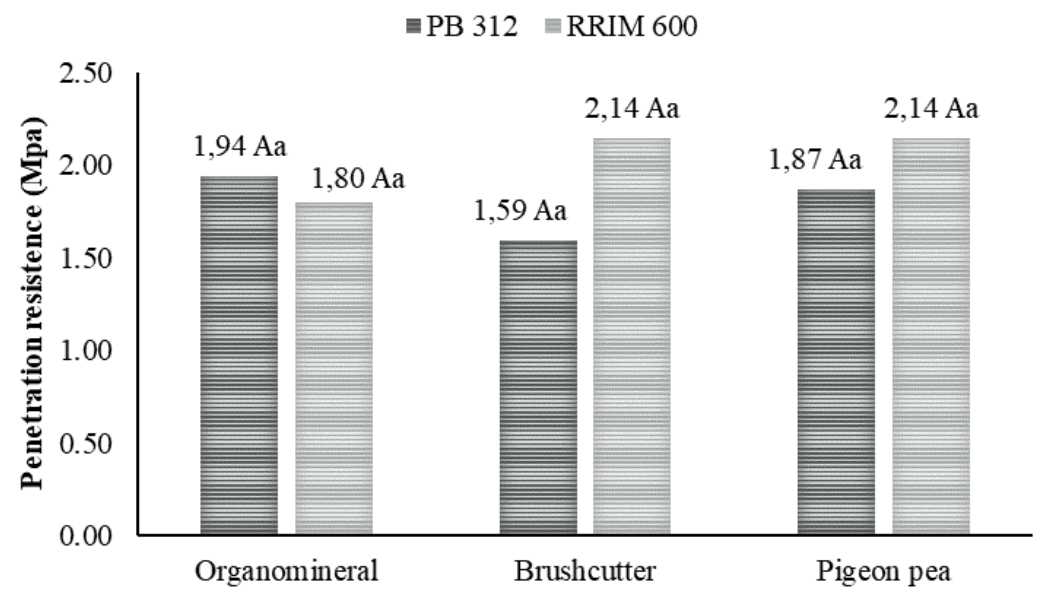

Figure 5. Mean penetration resistance (MPa) of a Red Latosol obtained after different fertilization management strategies in a rubber tree field. Uppercase letters compare management strategies within the same clone, while lowercase letters compare clones within the same management.

According to Lapen, Topp, Gregorich and Curnoe (2004), a PR of $2 \mathrm{MPa}$ is considered a critical average value for the root development of plants. However, Zou, Sands, Buchan and Hudson (2000) consider $3 \mathrm{MPa}$ as the restrictive limit for the development of forest species such as rubber trees. Therefore, the PR values found here are below the critical value for forest species.
The percentage of gravimetric soil moisture showed no significant differences between treatments (Figure 6), which is due to the absence of immediate response of organic matter contents in relation to the treatments. According to Costa, Alves and Souza (2016), organic matter leads to better soil water retention, which increases soil moisture.

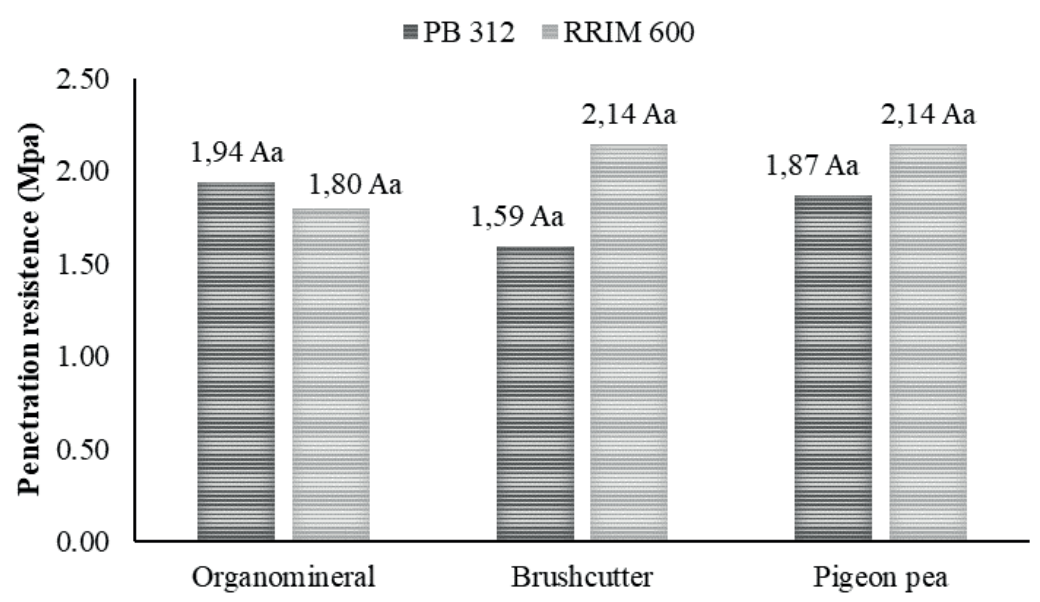

Figure 6. Mean gravimetric moisture (\%) of a Red Latosol obtained after different fertilization management strategies in a rubber tree field. Uppercase letters compare management strategies within the same clone, while lowercase letters compare clones within the same management. 


\section{Soil chemical attributes}

The results showed significant differences between treatments regarding the chemical variables $\mathrm{pH}$ and $\mathrm{H}+\mathrm{Al}$ (Table 2). Moreover, significant differences were also observed between clones for the chemical variables $\mathrm{pH}, \mathrm{Mg}, \mathrm{CEC}, \mathrm{V}, \mathrm{Al}$, and $\mathrm{m}$ (Table 3). Overall, management strategies had little effect on soil nutrient availability, but clones can influence soil chemical attributes.

Possibly, the amount of nutrients absorbed by plants due to different fertilizers was not ideal to influence rubber tree growth. Saufe, Sulaiman, Adekunle, Samad and Yusoff (2018) found a high increment in height and diameter of rubber trees in the treatment with $2.0 \mathrm{~g}$ of urea and $7.5 \mathrm{~g}$ of phosphorus per plant.
The analysis of soil $\mathrm{pH}$ showed differences between treatments. The organomineral fertilization provided the less acid soil and a decrease in the potential acidity value, which is in accordance with Carvalho, Moreira, Cruz, Fernandes and Oliveira (2014), who found the same benefits in olive trees fertilized with $50 \%$ of organomineral. However, these results are different from those found by Centurion, Centurion, Roque, Prado and Natale (2005), who observed a high $\mathrm{pH}$ under a soil management with tropical kudzu (Pueraria phaseoloide L.) associated with rubber trees compared to the management using harrow and brushcutter. Nascimento, Silva, Roberval and Silva (2005) observed a decrease in acidity using legumes such as pigeon pea.

\section{Table 2}

Means of chemical attributes for three management strategies (treatments): O - organomineral, BRU brushcutter, and PG - pigeon pea. Means followed by the same letter do not differ from each other by the Tukey test $(\mathbf{p}<0.05)$

\begin{tabular}{ccccc}
\hline \multirow{2}{*}{ Chemical attribute } & Unit & \multicolumn{3}{c}{ Treatment } \\
\cline { 3 - 5 } & & O & BRU & PG \\
\hline $\mathrm{pH}$ & $\mathrm{CaCl}_{2}$ & $5.13 \mathrm{a}$ & $4.97 \mathrm{ab}$ & $4.86 \mathrm{~b}$ \\
$\mathrm{Ca}$ & $\mathrm{cmol}_{\mathrm{c} \mathrm{dm}^{-3}}$ & $2.54 \mathrm{a}$ & $2.49 \mathrm{a}$ & $2.32 \mathrm{a}$ \\
$\mathrm{Mg}$ & $\mathrm{cmol}_{\mathrm{c} \mathrm{dm}^{-3}}$ & $1.02 \mathrm{a}$ & $1.01 \mathrm{a}$ & $0.95 \mathrm{a}$ \\
$\mathrm{H}+\mathrm{Al}$ & $\mathrm{cmol} \mathrm{dm}_{\mathrm{c}}^{-3}$ & $2.67 \mathrm{~b}$ & $3.06 \mathrm{ab}$ & $3.18 \mathrm{a}$ \\
$\mathrm{CEC}$ & $\mathrm{cmol} \mathrm{dm}_{\mathrm{c}}^{-3}$ & $6.64 \mathrm{a}$ & $6.90 \mathrm{a}$ & $6.78 \mathrm{a}$ \\
$\mathrm{P}$ & $\mathrm{mg} \mathrm{dm}^{-3}$ & $1.08 \mathrm{a}$ & $1.22 \mathrm{a}$ & $1.02 \mathrm{a}$ \\
$\mathrm{K}$ & $\mathrm{mg} \mathrm{dm}^{-3}$ & $159 \mathrm{a}$ & $125.50 \mathrm{a}$ & $127.50 \mathrm{a}$ \\
$\mathrm{OM}$ & $\%$ & $3.6 \mathrm{a}$ & $3.42 \mathrm{a}$ & $3.50 \mathrm{a}$ \\
$\mathrm{V}$ & $\%$ & $58.93 \mathrm{a}$ & $55.07 \mathrm{a}$ & $52.95 \mathrm{a}$ \\
$\mathrm{Al}$ & $0.04 \mathrm{a}$ & $0.10 \mathrm{a}$ & $0.09 \mathrm{a}$ \\
$\mathrm{m}$ & $\mathrm{cmol}_{\mathrm{c}} \mathrm{dm}^{-3}$ & $1.43 \mathrm{a}$ & $3.09 \mathrm{a}$ & $2.63 \mathrm{a}$ \\
\hline
\end{tabular}


Table 3

Means of chemical attributes for two rubber tree clones (PB312 and RRIM600). Means followed by the same letter do not differ from each other by the Tukey test $(\mathbf{p}<0.05)$

\begin{tabular}{|c|c|c|c|}
\hline \multirow{2}{*}{ Chemical attribute } & \multirow{2}{*}{ Unit } & \multicolumn{2}{|c|}{ Clone } \\
\hline & & PB 312 & RRIM 600 \\
\hline $\mathrm{pH}$ & $\mathrm{CaCl}_{2}$ & $4.85 \mathrm{~b}$ & $5.12 \mathrm{a}$ \\
\hline $\mathrm{Ca}$ & $\mathrm{cmol}_{\mathrm{c}} \mathrm{dm}^{-3}$ & $2.15 \mathrm{a}$ & $2.75 \mathrm{a}$ \\
\hline $\mathrm{Mg}^{2+}$ & $\mathrm{cmol}_{\mathrm{c}} \mathrm{dm}^{-3}$ & $0.88 \mathrm{~b}$ & $1.11 \mathrm{a}$ \\
\hline $\mathrm{H}+\mathrm{Al}$ & $\mathrm{cmol}_{\mathrm{c}} \mathrm{dm}^{-3}$ & $3.11 \mathrm{a}$ & $2.83 \mathrm{a}$ \\
\hline CEC & $\mathrm{cmol}_{\mathrm{c}} \mathrm{dm}^{-3}$ & $6.47 \mathrm{~b}$ & $7.07 \mathrm{a}$ \\
\hline $\mathrm{P}$ & $\mathrm{mg} \mathrm{dm}{ }^{-3}$ & $1.08 \mathrm{a}$ & $1.13 \mathrm{a}$ \\
\hline $\mathrm{K}$ & $\mathrm{mg} \mathrm{dm}{ }^{-3}$ & $128 \mathrm{a}$ & $146.67 \mathrm{a}$ \\
\hline $\mathrm{OM}$ & $\%$ & $3.55 \mathrm{a}$ & $3.46 \mathrm{a}$ \\
\hline $\mathrm{V}$ & $\%$ & $51.56 \mathrm{~b}$ & $59.74 \mathrm{a}$ \\
\hline $\mathrm{Al}^{3+}$ & $\mathrm{cmol}_{\mathrm{c}} \mathrm{dm}^{-3}$ & $0.12 \mathrm{a}$ & $0.04 \mathrm{~b}$ \\
\hline $\mathrm{m}$ & $\%$ & $3.82 \mathrm{a}$ & $0.95 b$ \\
\hline
\end{tabular}

No significant difference was observed between treatments for base saturation $(\mathrm{V})$, which differs from Corrêa, Grohskopf, Nicoloso, Lourenço and Martini (2016), who found a V of 77 using organomineral fertilization. In addition, no difference was observed between treatments for aluminum saturation (m), but the clone RRIM 600 showed the highest value. All $\mathrm{m}$ values were lower than $5 \%$ and are not harmful to nutrient availability for plants, according to the interpretation of Osaki (1991).

No significant statistical difference was observed between treatment means of cation exchange capacity (CEC). However, it was higher than the CEC values found by Carvalho, Moreira, Cruz, Oliveira and Fagundes (2015) in an olive tree field, with a value of approximately $5.60 \mathrm{cmol}_{\mathrm{c}} \mathrm{dm}^{-3}$. A difference was observed for CEC between clones. Clone RRIM 600 had the highest value, which is possibly related to its genetic and structural difference.

Nutrients $\mathrm{P}, \mathrm{K}, \mathrm{Ca}$, and $\mathrm{Mg}$ did not differ as a function of fertilization management strategy or clone, except for $\mathrm{Mg}$, which presented the highest concentration in the soil cultivated with the clone RRIM 600. Although the different fertilization management strategies, this statistical similarity found in the concentration of these nutrients reflects the availability rates of nutrients in the organic residues, as the levels observed in the organic and conventional fertilization were similar, thus evidencing the residue efficiency.

The concentrations of $\mathrm{P}, \mathrm{K}, \mathrm{Ca}$, and $\mathrm{Mg}$ at the same depth were $3.8 \mathrm{mg} \mathrm{dm}^{-3}, 269.72 \mathrm{mg} \mathrm{dm}^{-3}$, $6.15 \mathrm{mmol} \mathrm{dm}^{-3}$, and $1.95 \mathrm{mmol} \mathrm{dm}^{-3}$, respectively. Roque et al. (2005) found values of $12.63 \mathrm{mg} \mathrm{dm}^{-3}$, $55.11 \mathrm{mg} \mathrm{dm}^{-3}, 20.48 \mathrm{mmol}_{\mathrm{c}} \mathrm{dm}^{-3}$, and $8.79 \mathrm{mmol}_{\mathrm{c}}$ $\mathrm{dm}^{-3}$ for $\mathrm{P}, \mathrm{K}, \mathrm{Ca}$, and $\mathrm{Mg}$, respectively, for the clone RRIM 600 in Novo Horizonte, GO, Brazil. This difference between localities could be explained by the different edaphoclimatic characteristics.

The most marked difference was obtained as a function of the phosphorus level obtained by Roque, Prado, Natale, Beutler and Centurion (2004), who also evaluated coffee under a Red-Yellow Argisol in the Cerrado region. Oliveira, Ensinas, Barbosa, Nanzer and Barreta (2017) found levels of P, K, $\mathrm{Ca}$, and $\mathrm{Mg}$ of $3.82 \mathrm{mg} \mathrm{dm}^{-3}, 175.91 \mathrm{mg} \mathrm{dm}^{-3}, 1.10$ 
$\mathrm{mmol}_{\mathrm{c}} \mathrm{dm}^{-3}$, and $0.80 \mathrm{mmol}_{\mathrm{c}} \mathrm{dm}^{-3}$, respectively, in a single rubber tree system under a Quartzarenic Neosol, being similar to the results found in the present study due to similar environment conditions.

\section{Tree development}

The variable perimeter showed no statistical difference between treatments and between clones (Figure 7), and the variable height showed a statistical difference between clones (Figure 8).

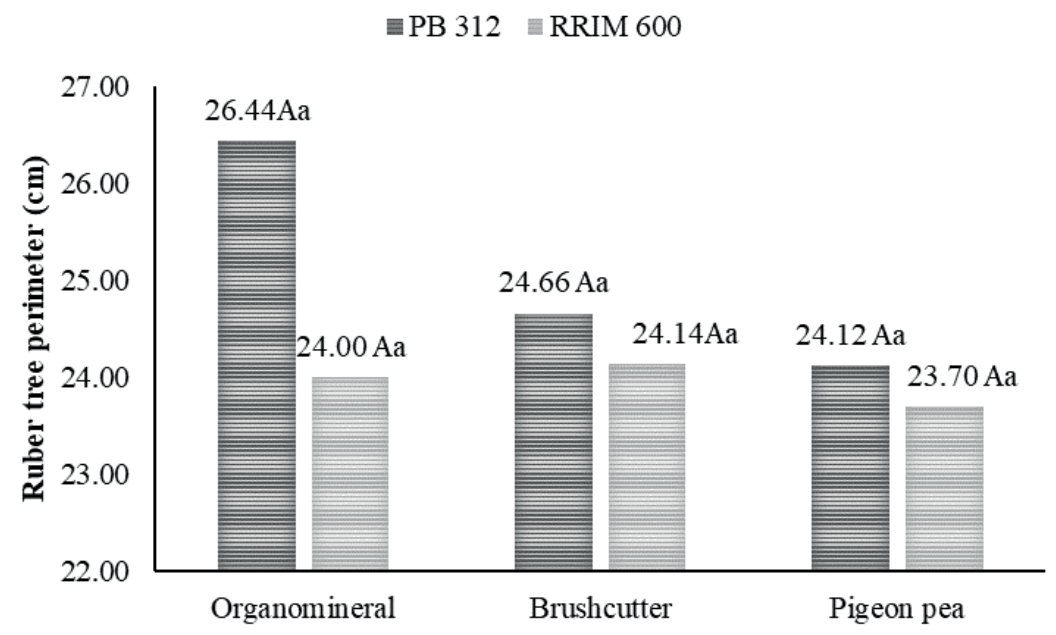

Figure 7. Means of perimeters at $1.2 \mathrm{~m}$ from the ground for the two clones under different treatments. Means followed by the same letter do not differ from each other by the Tukey test $(\mathrm{p}<0.05)$. Uppercase letters compare management strategies within the same clone, while lowercase letters compare clones within the same management.

를 312 RIM 600

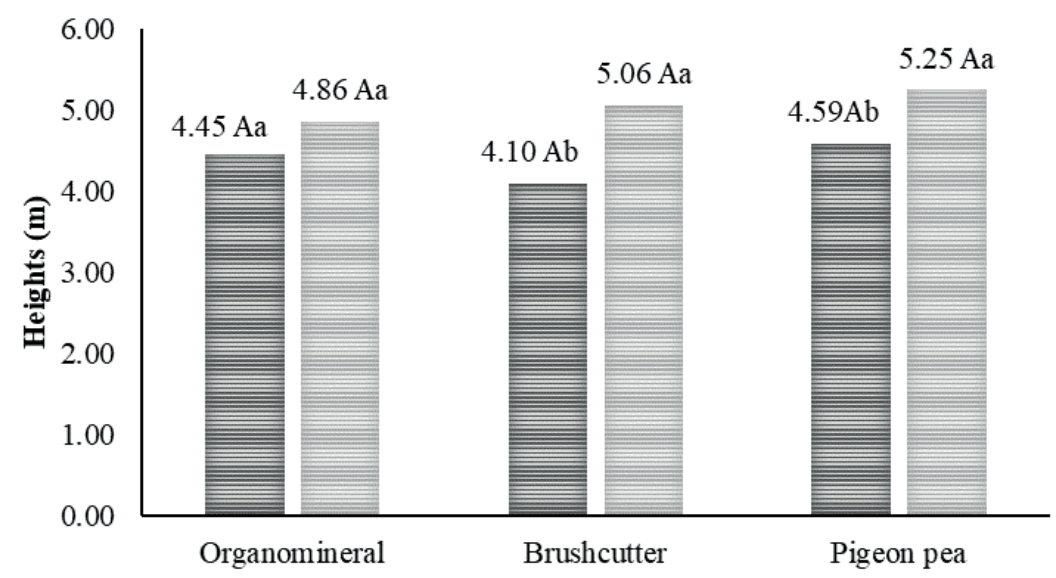

Figure 8. Means of heights for two clones under different treatments. Means followed by the same letter do not differ from each other by the Tukey test $(\mathrm{p}<0.05)$. Uppercase letters compare management strategies within the same clone, while lowercase letters compare clones within the same management. 
This difference in height can be explained by clone origin. Clone RRIM 600 showed the highest height values, which was already expected. This clone, developed by the Rubber Research Institute of Malaysia (RRIM), has tall trees, vertical stem, and fast growth when young. It belongs to class I, is used for planting on a large scale, and has a good performance in many places, such as the State of Goiás. However, it is suggested not to exceed $50 \%$ of the total area in small or medium rubber plantations. PB 312 is originated in Prang Besar, Malaysia, and belongs to the class III, which includes the clones recommended for planting up to $15 \%$ of the total area in aggregate blocks (IAC, 2018).

\section{Conclusions}

Because rubber trees provide several benefits in the economic, social, and environmental scopes, it is important to know its relationship with different soil and climate conditions found in Brazil. As shown in the results, the clone RRIM 600 had the best growth conditions, regardless of the management (fertilization), being the most recommended clone for the Cerrado biome under the conditions of a Red Latosol soil classification. The use of organomineral fertilizer made from poultry litter was efficient in reducing soil acidity, favoring rubber tree development. Because no differences were observed for soil physical attributes, it is essential to conduct this experiment continuously to prove which management is the most indicated.

\section{Acknowledgments}

To the State University of Goiás (UEG) for granting the professional master's degree. To ORGANOPLUS for donating the organomineral fertilizer used in this study. To the farm Baru for providing the area where this study was conducted.

\section{References}

Albornoz, F. (2016). Crop responses to nitrogen overfertilization: a review. Scientia Horticulturae, 205, 79-83. doi: 10.1016/j.scienta.2016.04.026

Almeida, R. F., Machado, H. A., Martins, F. P., Queiroz, I. D. S., Teixeira, W. G., Mikhael, J. E. R., \& Borges, E. N. (2014). Correlação do tamanho e distribuição dos agregados em Latossolos Amarelo da região do triângulo mineiro em diferentes ambientes. Bioscience Journal, 30(5), 1325-1334.

Alvarenga, R. C. (1993). Potencialidades de adubos verdes para conservação e recuperação de solos. Tese de doutorado, Universidade Federal de Viçosa, UFV, Viçosa, MG, Brazil.

Alvares, C. A., Stape, J. L., Sentelhas, P. C., Gonçalves, J. L. M., \& Sparovek, G. (2013). Köppen's climate classification map for Brazil. Meteorologische Zeitschrift, 22(6), 711-728. doi: 10.1127/0941-2948/ 2013/0507

Bertol, I., Alburquerque, J. A., Leite, D., Amaral, A. J., \& Zoldan, W. A., Jr. (2004). Propriedades físicas do solo sob preparo convencional e semeadura direta em rotação e sucessão de culturas, comparadas às do campo nativo. Revista Brasileira de Ciência do Solo, 28(1), 155-163. doi: 10.1590/S010006832004000100015

Cardoso, E. L., Silva, M. L. N., Moreira, F. M. S., \& Curi, N. (2009). Atributos biológicos indicadores da qualidade do solo em pastagem cultivada e nativa do Pantanal. Pesquisa Agropecuária Brasileira, 446(6), 631-637. doi: 10.1590/S0100-204X2009000600012

Carneiro, M. A. C., Souza, E. D., Reis, E. F., Pereira, H. S., \& Azevedo, W. R. (2009). Atributos físicos, químicos e biológicos de solo de Cerrado sob diferentes sistemas de uso e manejo. Revista Brasileira de Ciência do Solo, 33(1), 147-157. doi: 10.1590/S0100-06832009000100016

Carvalho, R. P., Moreira, R.A., Cruz, M. C. M., Fernandes, D. R., \& Oliveira, A. F. (2014). Organomineral fertilization on the chemical characteristics of Quartzarenic Neosol cultivated with olive tree. Scientia Horticulturae, 176, 120-126. doi: 10.1016/j. scienta.2014.07.006

Carvalho, R. P., Moreira, R. A., Cruz, M. D. C. M., Oliveira, A. F., \& Fagundes, M. C. P. (2015). Nutrition behavior of olive trees with the application of organomineral fertilizer. Comunicata Scientiae, 6(2), 224-233. doi: 10.14295/cs.v6i2.721 
Centurion, M. A. P. C., Centurion, J. F., Roque, C. G., Prado, R. M., \& Natale, W. (2005). Efeito do manejo da entrelinha da seringueira sobre as propriedades químicas do solo, o estado nutricional e o crescimento. Revista Árvore, 29(2), 185-193. doi: 10.1590/S0100-67622005000200002

Corrêa, J. C., Grohskopf, M. A., Nicoloso, R. S., Lourenço, K. S., \& Martini, R. (2016). Organic, organomineral, and mineral fertilizers with urease and nitrification inhibitors for wheat and corn under no-tillage. Pesquisa Agropecuária Brasileira, 51(8), 916-924. doi: 10.1590/S0100-204X 2016000800003

Costa, C. D. O., Alves, M. C., \& Souza, A. P. (2016). Armazenamento de água em dois solos sob diferentes usos e manejos. Revista de Ciências Ambientais, 10(2), 55-65. doi: 10.18316/1981-8858.16.31

Cunha, F. V., Neto, Pereira, M. G., Leles, P. S. S., \& Abel, E. L. S. (2018). Atributos químicos e físicos do solo em áreas sob diferentes coberturas florestais e pastagem em Além Paraíba - MG. Ciência Florestal, 28(1), 13-24. doi: 10.5902/1980509831569

Cunha, E. Q., Stone, L. F., Ferreira, E. P. B., Didonet, A. D., \& Moreira, J. A. A. (2012). Atributos físicos, químicos e biológicos de solo sob produção orgânica impactados por sistemas de cultivo. Revista Brasileira de Engenharia Agrícola e Ambiental, 16(1), 56-63. doi: 10.1590/S1415-43662012000100008

Empresa Brasileira de Pesquisa e Agropecuária (2013). Sistema brasileiro de classificação de solos (3a ed.). Brasília: EMBRAPA.

Empresa Brasileira de Pesquisa e Agropecuária (2017). Manual de métodos de análise do solo. (3a ed.). Brasília: EMBRAPA.

Ferreira, L. E., Souza, E. P., \& Chaves, A. F. (2012). Adubação verde e seu efeito sobre os atributos do solo. Revista Verde de Agroecologia e Desenvolvimento Sustentável, 7(1), 33-38.

Franzluebbers, A. J. (2002). Soil organic matter stratification ratio as an indicador of soil quality. Soil and Tillage Research, 66(2), 95-106. doi: 10.1016/ S0167-1987(02)00018-1

Galvão, J. R., Viegas, I. J. M., Oliveira, J. P., Silva, D. R., Yakuwa, T. K. M., \& Ribeiro, F. O. (2016). Crescimento de porta-enxertos de seringueira e teores de macronutrientes em um Latossolo Amarelo da Amazônia. Revista Inova Ciência \& Tecnologial Innovative Science \& Technology Journal, 2(3), 1421.
Good, A. G., \& Beatty, P. H. (2009). Fertilizing nature: a tragedy of excess in the commons. PLoS Biology, 9(8), e1001124. doi: 10.1371/journal.pbio.1001124

Instituto Agronômico de Campinas (2018). Centro de seringueira e sistemas agroflorestais clones. Recuperado de http://www.iac.sp.gov.br/ areasdepesquisa/seringueira/clones.php

Kemper, W. D., \& Chepil, W. S. (1965). Size distribution of aggregates. In C. A. Black (Ed.), Methods of soil analysis. Part 1. Agronomy (2nd ed., n. 9, pp. 499510). Wisconsin: American Society of Agronomy, Inc., Publishes, Madison.

Lapen, D. R., Topp, G. C., Gregorich, E. G., \& Curnoe, W. E. (2004). Least limiting water range indicators of soil quality and corn production, Eastern Ontario, Canada. Soil \& Tillage Research, 78(2), 151-170. doi: 10.1016/j.still.2004.02.004

Maggiotto, S. R., Oliveira, D., Marur, C. J., Stivari, S. M. S., Leclerc, M., \& Wagner-Riddle, C. (2014). Potential carbon sequestration in rubber tree plantations in the northwestern region of the Paraná State, Brazil. Acta Scientiarum. Agronomy, 36(2), 239-245. doi: 10.4025/actasciagron.v36i2.17404

Nanzer, M. C., Ensinas, S. C., Barbosa, G. F., Barreta, P. G. V., Oliveira, T. P., Silva, J. R. M., \& Paulino, L. A. (2019). Estoque de carbono orgânico total e fracionamento granulométrico da matéria orgânica em sistemas de uso do solo no Cerrado. Revista de Ciências Agroveterinárias, 18(1), 136-145. doi: $10.5965 / 223811711812019136$

Nascimento, J. T., Silva, I. F., Roberval, D. S., \& Silva, L. F., Neto. (2005). Efeito de leguminosas bis atributos físicos e carbono orgânico de um Luvissolo. Revista Brasileira de Ciência do Solo, 29(5), 825-831. doi: https://doi.org/10.1590/S0100-06832005000500018

Niero, L. A., Falci, S. C., Marques, C. R., \& Clerici, M. (2010). Avaliações visuais como índice de qualidade do solo e sua validação por análises físicas e químicas em um Latossolo Vermelho distroférrico com usos e manejos distintos. Revista Brasileira de Ciência do Solo, 34(4), 1271-1282. doi: 10.1590/ S0100-06832010000400025

Oku, E., Iwara, A., \& Ekukinam, E. (2012). Effects of age of rubber (Hevea brasiliensis Muell Arg.) plantation on $\mathrm{pH}$, organic carbon, organic matter, nitrogen and micronutrient status of Ultisols in the humid forest zone of Nigeria. Kasetsart Journal-Natural Science, 46(5), 684-693. 
Oliveira, T. P., Ensinas, S. C., Barbosa, G. F., Nanzer, M. C., \& Barreta, P. G. V. (2017). Atributos químicos de um Neossolo Quartzarênico de cerrado sob diferentes sistemas de uso e manejo. Revista de Agricultura Neotropical, 4(1), 72-78. doi: 10.32404/ rean.v4i5.2182

Osaki, F. (1991). Calagem e adubação. Campinas: Instituto Brasileiro de Ensino Agrícola.

Portugal, A. F., Juncksh, I., Schaefer, C. E. R. G., \& Neves, J. C. L. (2010). Estabilidade de agregados em argissolo sob diferentes usos, comparado com mata. Revista Ceres, 57(4), 545-553. doi: 10.1590/S0034$737 \mathrm{X} 2010000400018$

Pott, C. A., Zerbielli, L. C., Martins, P. J., Gardin, E., \& Garcia, M. L. (2017). Soil physical quality in forest, livestock and integrated production systems. Applied Research \& Agrotechnology, 10(2), 53-60. doi: 10.5935/PAeT.V10.N2.05

Reichert, J. M., Reinert, D. J., \& Braida, J. A. (2003). Qualidade dos solos e sustentabilidade de sistemas agrícolas. Ciência \& Ambiente, 14(27), 29-48.

Ribeiro, D. O., Carballal, M. R., Silva, A. J., Santos, T. E. B., Ferreira, L. L., \& Cunha, F. F. (2016). Produtividade de cana-de-açúcar e atributos de solo em função da aplicação de cama de peru. Revista de Ciências Agrárias, 59(3), 259-264. doi: 10.4322/ rca. 2215

Roque, C. G., Centurion, J. F., Pereira, G. T., Beutler, N. A., Freddi, O. S., \& Andrioli, I. (2005). Variabilidade espacial de atributos químicos em argissolo vermelho-amarelo cultivado com seringueira. Revista de Ciências Agro-Ambientais, 3(1), 26-45.

Roque, C. G., Prado, R. M., Natale, W., Beutler, N. A., \& Centurion, J. F. (2004). Estado nutricional e produtividade da seringueira em solo com calcário aplicado superficialmente. Pesquisa Agropecuária Brasileira, 39(5), 485-490. doi: 10.1590/S0100204X2004000500011

Rosa, P. A. L., Alves, M. C., Souza, E. J., Bonini, C. S. B., \& Videira, L. M. L. (2017). Adubos verdes, planta de cobertura, calagem e gessagem como forma de recuperação de um Latossolo Vermelho degradado. Revista Espacios, 38(29), 26-34.

Santos, A. C., \& Salcedo, I. H. (2010). Relevo e fertilidade do solo em diferentes estratos da cobertura vegetal na bacia hidrográfica da represa vaca brava, AreiaPB. Revista Árvore, 34(2), 277-285. doi: 10.1590/ S0100-67622010000200010
Saufe, N. A., Sulaiman, Z., Adekunle, S. M., Samad, M. Y. A., \& Yusoff, M. M. (2018). Influence of different rates of nitrogen $(\mathrm{N})$ and phosphorus $(\mathrm{P})$ fertilizers on growth and nutrient use efficiency of Hevea brasiliensis. European Journal of Engineering Research and Science, 3(3), 53-57. doi: 10.24018/ ejers.2018.3.3.628

Silveira, D. C., Melo, J. F., Fº, Sacramento, J. A. A. S., Silveira, E. C. P. (2010). Relação umidade versus resistência à penetração para um argissolo amarelo distrocoeso no recôncavo da Bahia. Revista Brasileira de Ciência do Solo, 34(3), 659-667. doi: 10.1590/S0100-06832010000300007

Souza, L. A., Silva, E. A., Oliveira, G. C., Barbosa, S. M., \& Silva, B. M. (2018). Análise qualitativa e quantitativa de agregados do solo sob filme plástico associado à fertilização organomineral em área cafeeira. Scientia Agraria, 19(2), 142-153. doi: 10.5380/rsa.v19i2.52826

Stolf, R. (1991). Teoria e teste experimental de fórmulas de transformação dosdados de penetrômetro de impacto em resistência do solo. Revista Brasileira de Ciência do Solo, 15(3), 229-235.

Torres, C. M. M. E., Jacovine, L. A. G., Brianezi, D., \& Alves, E. B. B. M. (2014). Sistemas agroflorestais no Brasil: uma abordagem sobre a estocagem de carbono. Pesquisa Florestal Brasileira, 34(79), 235244. doi: 10.4336/2014.pfb.34.79.633

Trabaquini, K., Galvão, L. S., Formaggio, A. R., \& Aragão, L. E. O. C. (2017). Soil, land use time, and sustainable intensification of agriculture in the Brazilian Cerrado region. Environmental monitoring and assessment, 189(2), 70. doi: 10.1007/s10661017-5787-8

Valani, G. P., Oliosi, G., Gontijo, I., \& Partelli, F. L. (2016). Estabilidade de agregados de solos com cafeeiro conilon e seringueira em monocultivo contrastado ao sistema agroflorestal. In Anais do Congresso Brasileiro de Pesquisas Cafeeiras, Serra Negra, SP, Brasil, 42.

Vasconcelos, R. F. B., Souza, E. R., Cantalice, J. R., \& Silva, L. S. (2014). Qualidade física de Latossolo Amarelo de tabuleiros costeiros em diferentes sistemas de manejo da cana-de-açúcar. Revista Brasileira de Engenharia Agrícola e Ambiental, 18(4), 381-386. doi: 10.1590/S1415-43662014000400004

Verheye, W. (2010). Growth and production of rubber. In Verheye, W. (Ed.). Land use, land cover and soil sciences (1st ed., pp. 20). Oxford, UK: UNESCOEOLSS Publishers. 
Yoder, R. E. (1936). A direct method of agregate analyses soil and a study of the physical nature of erosin losses. Journal America Society Agronomy, 28(3), 337-351.

Zaninetti, R. A., Moreira, A., \& Moraes, L. A. C. (2016). Atributos físicos, químicos e biológicos de Latossolo Amarelo na conversão de floresta primária para seringais na Amazônia. Pesquisa Agropecuária Brasileira, 51(9), 1061-1068. doi: 10.1590/s0100204x2016000900005
Zhang, Y., Zhou, Y., Chen, M., Zhang, L., Zhang, X., \& Sha, Y. (2017). Electrical tree initiation in silicone rubber under DC and polarity reversal voltages. Journal of Electrostatics, 88, 207-213. doi: 10.1016/j. elstat.2017.01.008

Zou, C., Sands, R., Buchan, G., \& Hudson, I. (2000). Least limiting water range: A potential indicator of physical quality of forest soils. Australian Journal of Soil Research, 38(5), 947-958. doi: 10.1071/ SR99108 